\title{
Effects of Explicit Instruction on Text Structure in Process Writing
}

\section{Sachi Oshima \\ Tsuda University}

\section{Reference Data:}

Oshima, S. (2020). Effects of explicit instruction on text structures in process writing. In P. Clements, A. Krause, \& R. Gentry (Eds.), Teacher efficacy, learner agency. Tokyo: JALT. https://doi.org/10.37546/JALTPCP2019-50

This study investigates the effectiveness of explicit instruction on text structure in the development of Japanese EFL college students' English writing skills by examining two research questions: (1) How does students' writing change after being given lessons on explicit instruction and process writing?; and (2) How do students' perceptions of English writing change due to process writing and explicit instruction on text structure? Two groups of students were given four lessons on process writing and explicit instruction. While one group of advanced-level students wrote an argumentative essay, the other group with beginner-level students wrote a descriptive essay. The results suggest that explicit instruction on text structure can be a useful means of developing English writing skills regardless of students' English proficiency levels. Students self-report indicated that their ability to organize ideas was highly improved, and they exhibited positive changes in writing in terms of organization and awareness of readers.

本研究では、EFL環境下にある日本人大学生を対象に、文章構成 (text structure) の明示的指導がライテイングにどのよう

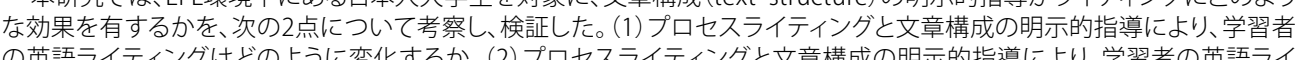
の英語ライテイングばのように变化するか。(2) プロセスライテイングと文章構成の明示的指嘎により学習者の英語ライ

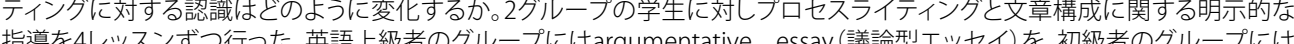
指導を4レッスンずつ行った。英語上級者のグループにはargumentative essay (議論型エッセイイを初級者のグループには

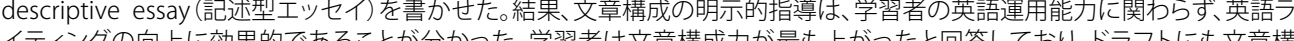
イテインクの同上に刘果的であるととがかった。学習者は文章構成力が最も上がったと回答してお以、゙ラフトにも文章構 成力の向上や゙読み手を意識した文章への变容といつた効果が表れた。

\begin{abstract}
any college English teachers in Japan are faced with the challenge of how to help improve academic writing skills of students who learn English as a foreign language (EFL). International tests indicate that compared to listening, reading, and speaking skills, Japanese students' English writing skills tend to be lower. For example, the latest data of Academic Test of IELTS (the International English Language Testing System) which measures proficiency in academic English by 0-9 band scales, Japanese test-takers in 2018 excelled at reading (mean score 6.06), followed by listening (5.88) and speaking (5.56), but they marked the lowest score at writing (5.43) (IELTS, 2020). In the classroom, Japanese college teachers frequently find students' poor performances in writing such as the lack of coherence and an unorganized text.
\end{abstract}

Indeed, college teachers need to understand what students have learned about English writing before entering a university. A survey by Benesse Educational Research and Development Institute (BERD) (2015) provides useful information. First, in senior high schools, students were given more grammar instruction and fewer writing activities. $89.4 \%$ of senior high school teachers gave grammar instruction. On the other hand, $43 \%$ of them have their students write their own ideas in English, and only $28.9 \%$ of them let their students write summaries in English. Secondly, in both junior and senior high schools, a lot of Japanese teachers of English (JTEs) think that creating an opportunity for students to express their ideas in English is very important; however, few JTEs achieve this. $66.8 \%$ of senior high school teachers think creating an opportunity is important, but only $9.9 \%$ reported that they sufficiently achieved this. From the results of this survey, it can be said that Japanese college students do not have enough experience in writing English before entering a university.

Considering the students' readiness, as shown above, it is a great challenge for Japanese EFL college students to understand the text structure of English writing, logically organize their idea, and coherently write English texts. Above all, in process writing, which has been frequently introduced in English writing lessons in Japan, it would be just unmotivating, boring exercises for students if they are asked to rewrite 
sentences without understanding the text structure of English, in other words, without understanding what they are expected to write. Hyland (2003) pointed out that it is important for students not only to learn how to write but also to understand how English texts are shaped or organized.

This study, thus, aims to investigate an effective way to teach English writing to Japanese college students. More specifically, by implementing the lessons using process writing and explicit instruction on text structure, this study examines whether and how explicit instruction on text structure is effective for students to write their essays and develop their writing skills. It also examines whether explicit instruction on text structure can be an effective means for students at different levels.

\section{Theoretical Background}

Differences between Japanese and English Texts

One of the difficulties with which Japanese EFL students are faced in English writing is differences in how texts are structured in English and Japanese. Looking at a paragraph, an English paragraph should consist of a topic sentence, supporting sentences, and a concluding sentence. The topic sentence is most important and tells readers the main idea of the paragraph. The supporting sentences are written next for explaining the main idea. The concluding sentence signals the end of the paragraph and restates the main idea. On the other hand, a Japanese paragraph does not always have a topic sentence. In many cases, the writer first explains the background information, gives examples, develops ideas, and finally puts the main idea as a conclusion.

The above-mentioned difference can be explained as to whether the language tends toward a deductive style or an inductive style. Hinds (1990) suggested that English writing can be said to be organized in a deductive style; the topic sentence or the main idea comes first, followed by supporting details such as reasons, examples, and explanations. On the other hand, Japanese writing is more inductive in style, in which supporting details are written first and the topic sentence appears next.

Another difference is, as Hinds (1987) explained, that English is a writer-responsible language, while Japanese is a reader-responsible language. In Japanese, readers are usually expected to make the necessary effort to understand the meaning from the texts; however, in English, it is writers who must make the meaning clear for the readers. Hyland (2003) also suggested that, in English texts, "good writers are people who are better able to imagine how their readers will respond to their texts" (p. 49).
Differences in text structures between English and Japanese make it difficult for Japanese EFL students to write organized English texts. Even though they successfully write their ideas in grammatically correct English sentences, without knowledge on English text structure, Japanese students have no choice but to put these English sentences in the Japanese text order. Hinds (1990) suggested that the difficulties with which EFL students are faced in English writing are "often due to an inadequate understanding of how texts are organized" (p. 66) and that direct translations from Japanese texts will bring "a frequent feeling that the composition is disorganized, unfocused, or ineffective" (p. 90). Unless they understand how English texts should be structured, Japanese students would continue using the Japanese text structure because it is natural for them. It appears that Japanese EFL students need to understand how English texts are typically organized, and that is why the researcher of this study finds it necessary to give explicit instruction on the English text structure in process writing.

\section{Explicit Instruction on Text Structure}

Explicit instruction can be generally explained as a way to teach students skills, knowledge, and strategies by using explicit, direct, and focused instruction. Compared with implicit instruction, which encourages students to gain knowledge through exposure, explicit instruction is more effective for learners to use targeted features more accurately (for example, Norris \& Ortega, 2000; Kirschner, Sweller \& Clark, 2006: Li, Ellis \& Zhu, 2016). Especially in teaching writing for EFL students or those who are nonnative speakers (NNS) of English, Hinkel (2003) pointed out that "without instruction in and learning how to construct L2 academic text, NNS students often find themselves at a great disadvantage in their academic and professional careers" (p. 35).

Some previous studies have uncovered the positive effects of explicit instruction on students' writing performance. In teaching writing, explicit instruction refers to "explicitly teaching students writing knowledge and strategies to plan, write, and revise texts" (De Smedt, Graham \& Van Keer, 2019, p. 154). Amer (2013) conducted an action research targeting EFL Palestinian university students. The students wrote essays before and after the teacher's explicit instruction on the organizational patterns of essays on comparison and contrast. The student's pre- and post- instruction essays and their pre- and postinstruction interviews were analyzed. The author concluded that "students receiving explicit instruction in the rhetorical structures of expository texts are able to construct their own expository texts effectively" (Amer, 2013, p. 236). De Smedt, Graham, and Van Keer (2019) conducted an experimental study targeting fifth- and sixth-grade students in primary schools in Belgium and investigated the impact of explicit instruction on students' 
writing motivation. Teachers of the experimental group explicitly introduced the model of descriptive texts and taught how to plan, write, and revise descriptive texts. Comparing the experimental group with explicit instruction with the control group without it, the experimental group had higher motivation for English writing.

Both of these studies supported the effectiveness of explicit instruction on text structure; however, studies targeting Japanese EFL students are not sufficient enough, and several variables should be also examined to ensure the effectiveness of explicit instruction. Considering Japanese EFL college students, at least the following two variables should be examined.

- Is explicit instruction on text structure effective for students at different levels?

- Is the effectiveness of explicit instruction, if any, applicable to other genres of essays?

This study, thus, aims to examine whether the explicit instruction on text structure is effective in two different classes, at different English proficiency levels, using writing different essay genres.

\section{Process Writing and Teacher's Feedback}

In process writing, students organize their ideas, write multiple drafts, get feedback from teachers and classmates, revise their drafts multiple times, and finally, complete the final document. Although there are different terms used to describe process writing, the typical models consist of four stages; (i) prewriting/generating, (ii) composing/drafting, (iii) revising/reshaping, and (iv) evaluating/editing (Badger \& White, 2000; Hyland, 2003; White \& Arndt, 1991). Process writing is sometimes misunderstood that teachers are just checking grammatical errors in each draft. However, as White and Arndt (1991) suggested, process writing is "not merely a boring error-checking exercise" (p. 5), but a complex thinking process. They explained that, in process writing, "writers are faced with a very complex management problem because they [learners] are darting back and forth from one process to another in real time" (White \& Arndt, 1991, p. 4).

In process writing, a teacher's feedback plays an important role. Hyland $(2003,2018)$ suggested that, after providing explicit instruction on text structure, effective feedback seems to be on the structure and organizational features. Considering Japanese EFL college students, who have experienced more grammar instruction and fewer writing activities before entering a university (BERD, 2015), teachers need to not only check grammatical errors but also to provide sufficient instruction in terms of how to organize ideas coherently.

\section{Research Questions}

Based on these implications, this study examines the effectiveness of explicit instruction on text structure in the development of Japanese EFL college students' English writing. It therefore poses the following two research questions:

1. How does students' writing change after being given lessons on explicit instruction and process writing?

2. How do students' perceptions of English writing change due to process writing and explicit instruction on text structure?

Method

Study Design

The research carried out in this study uses an action research design (Wallace, 1998), which is carried out by the teacher herself. As mentioned above, it was important to look into two variables: students' English proficiency levels and essay genre types. Therefore, two studies were carried out to examine whether the same approach is effective in two different classes. Table 1 below is a summary of the variables and participants.

\section{Participants}

All participants in both Study 1 and Study 2 gave informed consent to the researcher, and the project was cleared with the university's institutional review board.

Study 1: 33 Japanese college students were given four face-to-face lessons ( 90 minutes each) for writing an argumentative essay as well as supplementary instruction via e-mail. All of them were sophomore and non-English majors. Their proficiency level was from high-intermediate to advanced.

Study 2: 13 Japanese college students were given four face-to-face lessons (90 minutes each) for writing a descriptive essay as well as supplementary instruction via e-mail. All of them were sophomore and non-English majors. Their proficiency level was beginners.

\section{Type of Essay Used}

An argumentative essay was used for students in Study 1, while a descriptive essay was used for students in Study 2 
Table 1. Participants of Study 1 and 2

\begin{tabular}{lll}
\hline & \multicolumn{1}{c}{ Study 1 } & \multicolumn{1}{c}{ Study $\mathbf{~}$} \\
\hline Number of Students & 33 & 13 \\
Grade & Sophomore & Sophomore \\
Majors & Non-English Majors & Non-English Majors \\
Number of Lessons & 4 Lessons (90 min. each) & 4 Lessons (90 min. each) \\
English Proficiency & High-intermediate or & Beginners \\
& Advanced & \\
Essay Genres & Argumentative & Descriptive \\
\hline
\end{tabular}

\section{Procedure}

The lessons were conducted for four weeks by the researcher of this study. Study 2 was conducted in the same manner and procedure after completing Study 1 . The students in both Study 1 and Study 2 went through the following phases.

\section{Lesson 1: Preliminary}

The first lesson deals with prewriting/generating among the four stages of process writing. The scope of writing is to have the students generate ideas, connect ideas into an organized way, and write an outline of an essay.

Before starting writing, the teacher explicitly introduced the structure of an essayargumentative in Study 1 and descriptive in Study 2. The teacher made her original handout (see Appendix A) and explained how each sentence is connected in a paragraph, and how each paragraph is connected in a whole essay. Using this original handout, the teacher had the students analyze a model essay. For Study 1, the model essay was taken from the students' textbook, Longman Academic Writing Series 4 (Pearson Education), and for Study 2, the mode essay was made by the teacher based on several online resources. In this phase, the focus was on the structure of an argumentative or descriptive essay. The teacher referred to her origina handout again and again and drew a picture on the whiteboard (Figure 1). Then, the teacher provided an essay prompt (see Appendix B \& Appendix C), showed how to write an outline, and had the students start writing an outline.

After the lesson 1, the students completed their writing at home and submitted the assignment by email before the next lesson. If the students had any questions or problems in revising their drafts, they could always consult the teacher via e-mail. The teacher wrote her comments and feedback on each draft and brought them to the next lesson.

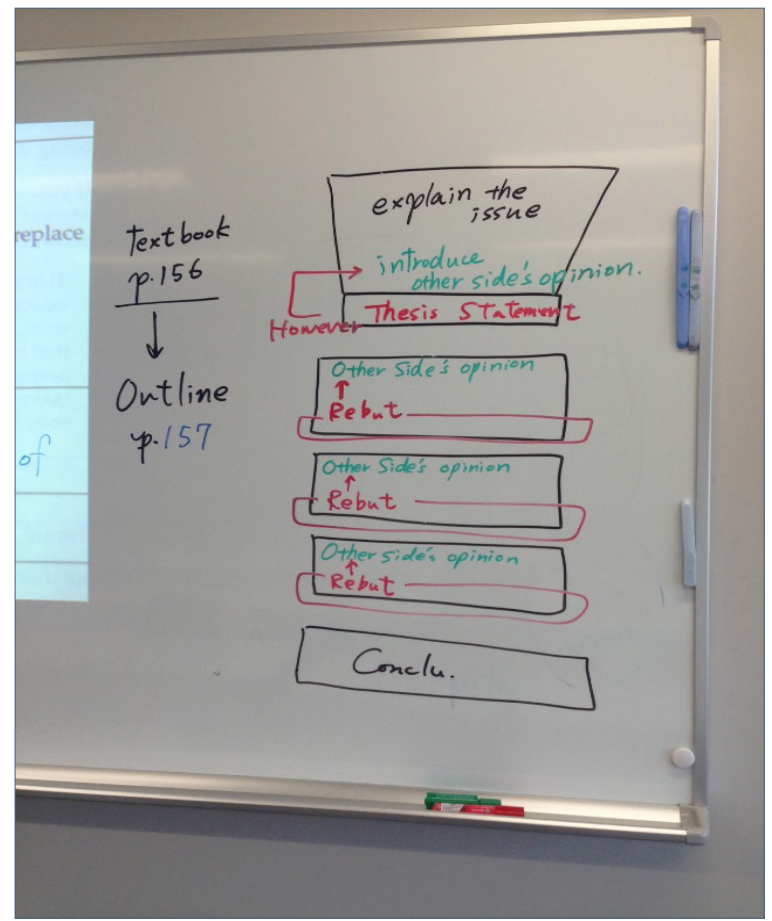

Figure 1. Teacher's explanation on the whiteboard (argumentative essay)

\section{Lesson 2: Writing Draft 1}

The second lesson deals with composing/drafting among the four stages of process writing. While some students had already successfully written their outlines, others seemed to find it difficult to put their ideas in the proper text structure and just wrote words on paper. Therefore, the scope of writing is to have the students deepen their understanding of the structure of an argumentative/descriptive essay, coherently connect ideas, and write the first draft.

At the beginning of the second lesson, the teacher reviewed the structure of an argumentative or descriptive essay and shared common mistakes among the students' 
outlines. The teacher had the students look at the handout (see Appendix A) again and drew a picture of the text structure on the whiteboard (Figure 1). The teacher then returned each student's outline with her comments. The teacher's feedback was focused on coherence. More specifically, the teacher made comments on each outline based on whether each student logically organized their idea according to the structure of an argumentative or descriptive essay. Individual conferences for the students were also held if needed. After the lesson 2, the students completed their first draft at home and submitted the assignment by email before the next lesson.

\section{Lesson 3: Writing Draft 2}

In the third lesson, revising/reshaping was focused on among the four stages of process writing. The teacher again explicitly reviewed the structure of an argumentative or descriptive essay by using the handout (see Appendix A) and drawing the picture on the whiteboard (Figure 1). After that, the teacher returned each student's draft 1 with her comments. The teacher's feedback was focused on coherence and organizational features such as the use of signposts. The teacher did not just point out mistakes, but also gave concrete suggestions about how to organize the students' ideas. After the lesson 3, the students completed their second draft at home and submitted the assignment by email before the next lesson.

\section{Lesson 4: Writing Final Draft}

The fourth lesson deals with evaluating/editing among the four stages of process writing. The teacher, once again, reviewed the structure of an argumentative or descriptive essay and shared common mistakes among students' drafts 2 . Then, the teacher returned each student's draft 2 with her comments. White and Arndt (1991) suggested that, when writing the final draft, students are making the transition from "the writer-based" to "reader-based" writing so that "the concerns of the reader should now begin to assume more significance" (p. 99). Therefore, in addition to coherence, the teacher's feedback for the draft 2 was focused on awareness of readers. When the students wrote something unclear to the reader, the teacher wrote comments such as "What is XX?" and "Add more explanation." After the lesson 4, the students completed their final draft at home.

After the Lessons: The Questionnaire

After the submission of the final draft, an open-ended questionnaire (see Appendix D) was conducted in the students' L1 (Japanese). To get the students' honest and frank opinions, the researcher conducted the anonymous questionnaire which did not require the students' names.

The students' answers were categorized by keywords such as "organization" and "grammar," and the researcher counted how many times the students referred to these keywords. Questionnaire items and the students' answers cited in this paper were translated from Japanese to English by the researcher.

\section{Results \& Discussion}

Effect of Explicit Instruction on the Students' Ability to Organize Ideas Regarding the research question (1), the students in Study 1 and Study 2 showed a similar tendency; the students' writing in both groups exhibited positive changes in logical organization.

Looking at Draft 1 written by the advanced-level female Student A in Study 1, she initially failed to use the conjunctive adverb "however." The word "however" should show contrast, but she could not establish the opposite information in Draft 1 . By the process of revising drafts, she was able to put a transitional sentence to clearly show contrasting ideas and could introduce her thesis statement more effectively (Table 2).

$$
\text { Table 2. Introduction Paragraph by Student A in Study } 1
$$

Draft 1 Although some argue that it costs to purchase newspapers and newspapers contain miscellaneous information, others are concerned about the loss of paper resources. However, newspapers are not a thing of the past.

Final Some argue that it costs to purchase newspapers and that newspapers

Draft contain miscellaneous information, and others are concerned about the loss of paper resources. Setting the reasons aside, both of them claim that newspapers are already obsolete. However, newspapers are not a thing of the past.

Note. Emphasis added.

The positive influence on logical organization was also shown in the students' drafts in Study 2. In the introduction paragraph in an academic essay in English, it is expected that the writer first provides general information, gradually narrows down the information, and then writes the thesis statement (Oshima \& Hogue, 2014). Looking at the drafts 
written by the beginner-level male Student B in Study 2, he initially failed to put information in the expected order; however, by explicit instruction on the text structure, he revised his draft so that each piece of information was more logically ordered (Table 3).

Table 3. Introduction Paragraph by Student B in Study 2

Draft 1 I'm student at a XX university. My major is business administration. The university is divided into nine departments. $\mathrm{XX}$ university is a university located in YY. Not only the university but also there are kindergartens, elementary school, junior and high school. I would like to explain what the management faculty of this university is learning. I will introduce three unique subjects.

Final I'm a student at XX University. XX University is a university located in YY.

Draft There are not only the university but also kindergarten, elementary school, junior and high school. The university is divided into eight departments and my major is business administration. I will explain what students of the Management Faculty are learning. Especially I will introduce three unique subjects.

Note. Emphasis added.

Effects of Explicit Instruction on the Students' Awareness of Readers The students' writing also showed the enhancement of students' awareness of readers. Through revising drafts, the students in both groups began to add more information and describe the content in more detail. This can be regarded as the students becoming able to "imagine how their readers will respond to their texts" (Hyland, 2003, p. 49). For example, the advanced-level female Student $C$ in Study 1 elaborated her explanation about "Zama case" so that the readers can understand the content more precisely (Table 4).
Table 4. Introduction Paragraph by Student C in Study 1

\begin{tabular}{l|l} 
Draft 1 & ...Thus, people have growing doubts about the way Japanese media reports
\end{tabular} about violent crimes. For example, in Zama case, the victims were...

Final ...Thus, people have growing doubts about the way how Japanese media Draft report violent crimes. For example, in Zama case in which nine people were killed in Zama City in 2018, the victims were..

Note. Emphasis added.

Student D in Study 2 also developed his description. In his first draft, what he means by the phrase, "I saw the whole university" was unclear. Therefore, the teacher wrote her comments, "What do you mean? What did you see? Did you only 'see' the university, or did you hear something? Explain in more detail." Then, he included a lot of detailed information in his final draft and successfully made his meanings clearer to the readers (Table 5).

Table 5. Body Paragraph by Student D in Study 2

Draft 1 The first lecture contents are first grader seminars. At the beginning of the lecture I saw the whole university. I will design the future after graduating from college.

Final $\quad$ The first subject is First Grader Seminars. At the beginning of subject, I

Draft heard the explanation of the university campus. I heard usage of library and Running [Learning] Commons and the explanation of lecture contents. I designed the university in the future after the graduation.

Note. Emphasis added.

Students' Perceptions of Explicit Instruction and Process Writing Regarding the research question (2), the students' answers in the questionnaire showed similar results between Study 1 and Study 2. First, both groups reported that their ability to organize ideas was improved (Figure 2). In both groups, "the organization/structure occupied the most, and "word choice" followed. On the other hand, while the students in Study 1 mentioned "citation" and "research skills," none of the students in Study 2 mentioned these. This difference was caused by the difference in essay prompts; that is, 
while the students in Study 1 had to do some research on media (see Appendix B), the students in Study 2 did not necessarily do this because they could describe the subjects they were taking in their university (see Appendix C).
Study 1

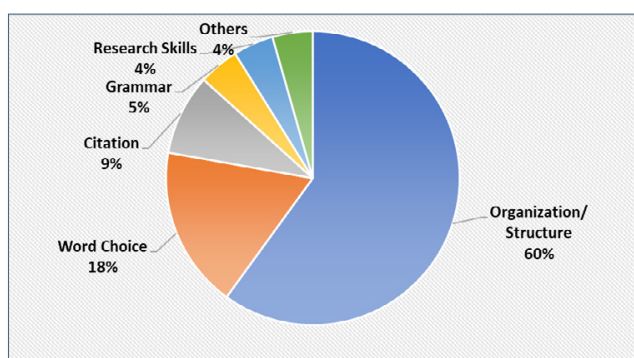

Study 2

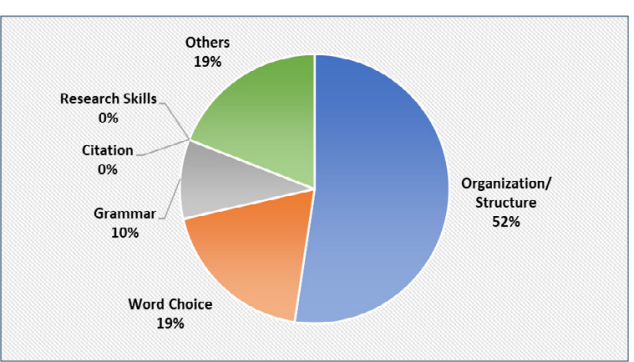

Figure 2. Students' answers to the question, "What aspects of writing skills do you think were developed?"

In addition to explicit instruction on text structure, a teacher's feedback is important while the students are at revising and editing stages in process writing. In response to the question in the students' questionnaire, "What do you think was beneficial for improving your writing?", the students in both groups put the highest value on the teacher's feedback and instruction (Figure 3), and the students similarly preferred the teacher's comments and suggestions to just indicating the location of errors (Figure 4).
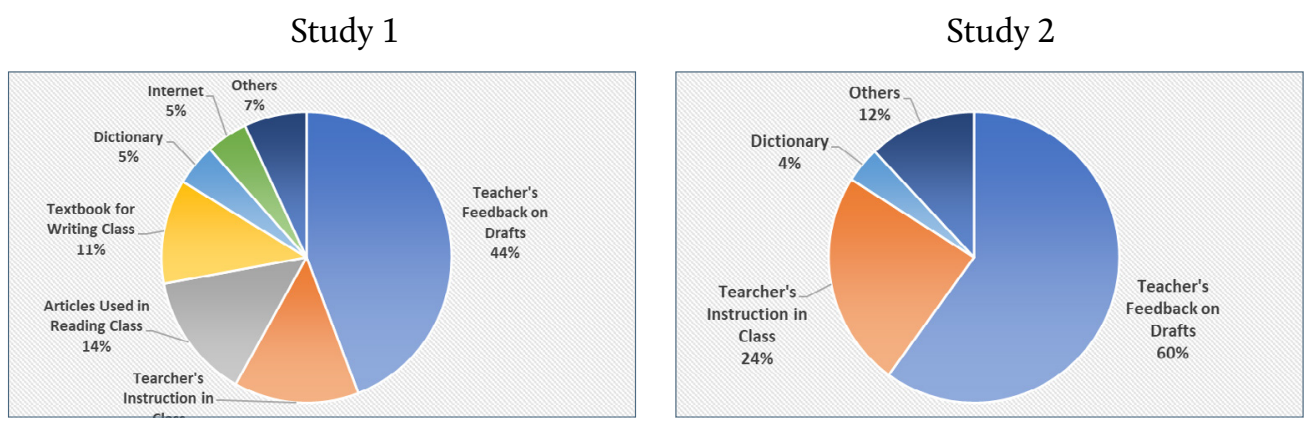

Figure 3. Students' answers to the question, "What do you think was beneficial for improving your writing?"
Study 1

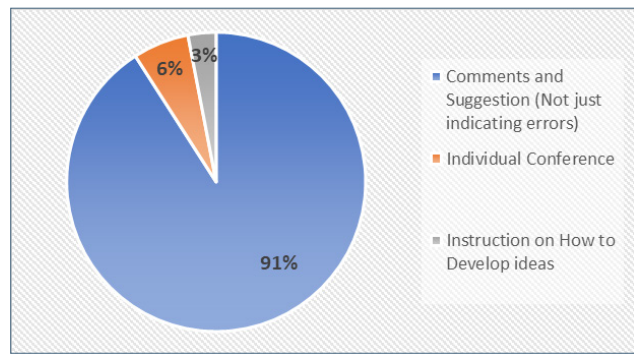

Figure 4. Students' preference for teacher feedback

\section{Conclusion}

This study investigated the effectiveness of explicit instruction on text structure in the development of Japanese EFL college students' English writing. Despite the small number of participants, the students, both in Study 1 and in Study 2, reported in the questionnaire that their ability to organize ideas improved through process writing. They exhibited positive changes in their drafts in terms of logical organization and their awareness of readers. From these positive changes, it can be said that the students began to overcome the previously described difficulties which Japanese EFL students have when writing an essay in English: the differences in how texts are structured in Japanese and English. Finally, the students put the highest value on the teacher's feedback. Above all, they preferred the teacher's detailed comments and suggestions to just indicating where they made an error. These results were applicable regardless of students' English proficiency levels and essay genre types; therefore, it can be concluded that explicit instruction on text structure together with process writing is effective to improve Japanese EFL college students' writing.

\section{Acknowledgment}

The presentation at the 2019 JALT International Conference on November 2, 2019 was made possible by the support of the 2019 JALT Fee Waiver Scholarship. 


\section{Bio Data}

Sachi Oshima is a research fellow at the Research Institute for Policy Studies, Tsuda University. After working at the Japan Foundation as a program officer, she is a teacher at Tsuda University, Shibaura Institute of Technology, Tamagawa University, and Tokyo Future University. Her research interests are related to TESOL and intercultural exchange projects. <s-oshima@tsuda.ac.jp>

\section{References}

Amer, M. (2013). The effect of explicit instruction in expository text structure on the writing performance of Arab EFL university students. Arab World English Journal, 1(4), 224-238. Retrieved from https://www.awej.org/index.php/volume-4-2013/32-awej-volume-4-number-1-2013/213mosheer-amer

Badger, R. \& White, G. (2000). A process genre approach to teaching writing. ELT Journal, 54(2), 153-160. https//doi.org/10.1093/let/54.2.153

Benesse Educational Research and Development Institute. (2015). 中高の英語指導に関する実態調査 2015 [Survey on English instruction in Japanese lower and upper secondary schools]. Retrieved from https://berd.benesse.jp/up_images/research/Eigo_Shido_all.pdf

De Smedt, F., Graham, S. \& Van Keer, H. (2019). The bright and dark side of writing motivation: Effects of explicit instruction and peer assistance. The Journal of Educational Research, 112(2), 152-167. https//doi.org/10.1080/00220671.2018.1461598

Hinds, J. (1987). Reader versus writer responsibility: A new typology. In U. Connors \& R. B. Kaplan (Eds.), Writing across languages: Analysis of L2 text. Reading, MA: Addison-Wesley.

Hinds, J. (1990). Inductive, deductive, quasi-inductive: Japanese, Korean, Chinese, Thai. In U. Connors \& A. M. Johns (Eds.), Coherence in writing: Research and pedagogical perspectives. (pp. 89109). Alexandria, VA: TESOL.

Hinkel, E. (2003). Teaching academic ESL writing. NY: Routledge. https://doi. org/10.4324/9781410609427

Hyland, K. (2003). Second language writing. Cambridge, U. K.: Cambridge University Press.

Hyland, K. (2018). Genre-based pedagogies: A social response to process. In K. Hyland (Ed.), The essential Hyland: Studies in applied linguistics. (pp. 392-403). London: Bloomsbury Academic.

IELTS. (2020). Mean band score for the most frequent nationalities (Academic). Test taker performance 2018. Retrieved from https://www.ielts.org/teaching-and-research/test-takerperformance
Kirschner, P.A., Sweller, J. \& Clark, R.E. (2006). Why minimal guidance during instruction does not work: An analysis of the failure of constructivist, discovery, problem-based, experiential, and inquiry-based teaching. Educational Psychologist, 41(2), 75-86. https://doi.org/10.1207/ s15326985ep4102_1

Li, S., Ellis, R. \& Zhu, Y. (2016). Task-based versus task-supported language instruction: An experimental study. Annual Review of Applied Linguistics, 36, 205-229. https://doi.org/10.1017/ S0267190515000069

Norris, J.M. \& Ortega, L. (2000). Effectiveness of L2 instruction: A research synthesis and quantitative meta-analysis. Language Learning, 50(3), 417-528. https://doi.org/10.1111/00238333.00136

Oshima, A., \& Hogue, A. (2014). Longman academic writing series 3 (4th ed.). White Plains, NY: Pearson Education.

Wallace, M.J. (1998). Action research for language teachers. Cambridge: Cambridge University Press. White, R., \& Arndt, V. (1991). Process writing. London: Longman. 


\section{Appendix A}

Handout Used in Class

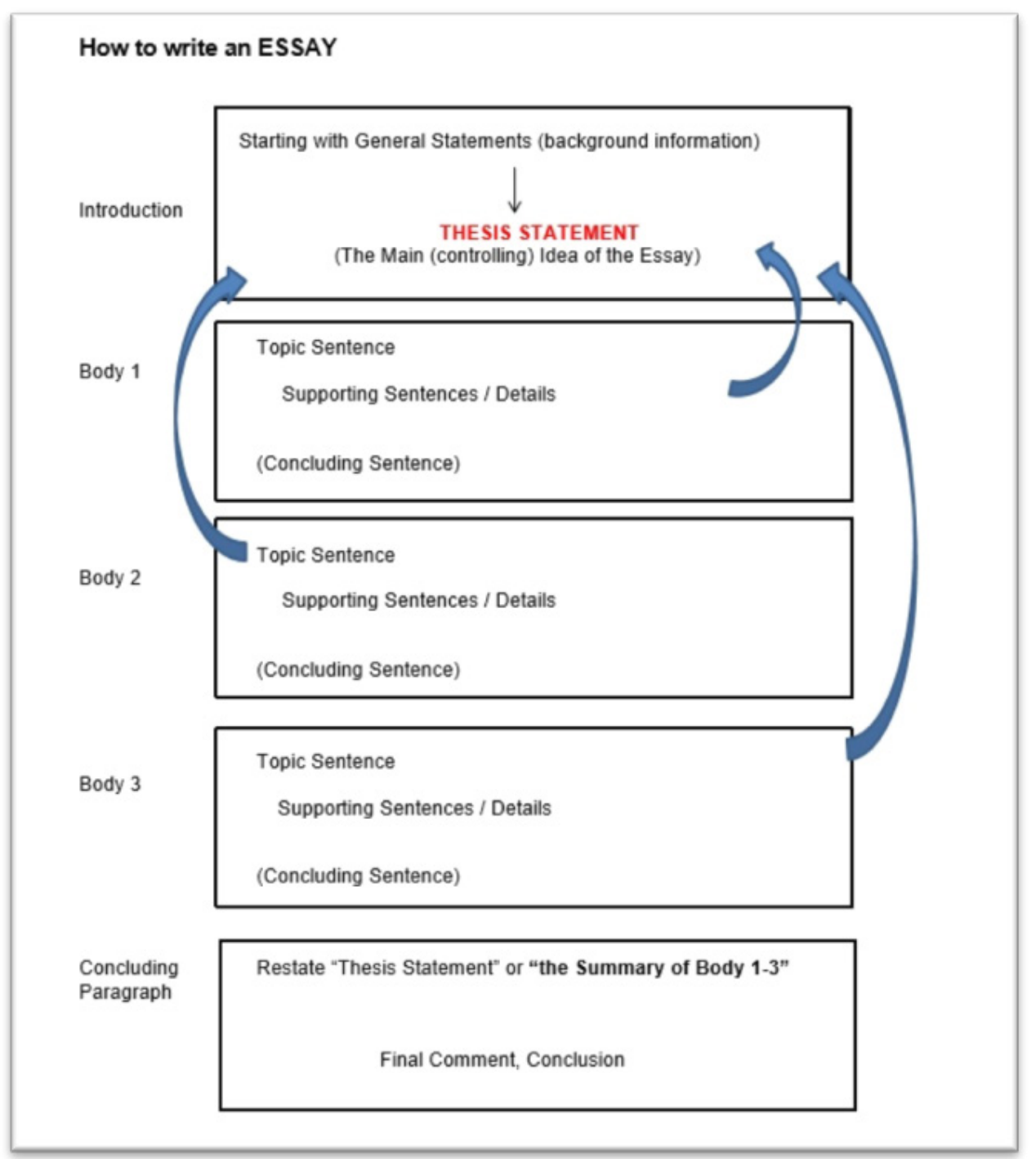

\section{Appendix B \\ Essay Prompt for an Argumentative Essay}

You will write an Argumentative Essay (5-7 paragraphs) on one of the following topics.

1. Choose one topic, explain it, and state your opinion with a clear thesis statement.

- Social media creates isolation.

- Social Network Service (SNS) is responsible for fake news.

- The media should be restricted when reporting violent crimes.

- Newspapers are a thing of the past.

2. In your Body Paragraphs,

i. Introduce the other side's argument, and

ii. REBUT with your own counterargument.

Write reasons and details to support your arguments. Use articles, data, or statistics.

3. Don't forget to make a "Works Cited" page at the end of the essay. 


\section{Appendix C \\ Essay Prompt of a Descriptive Essay}

\section{You belong to XX University and are taking various subjects.}

Describe three subjects in detail you have studied to the readers who know nothing about XX University.

\section{Essay Organization:}

Introduction Paragraph:

At the beginning, you will provide general information. After narrowing down the information, you will write a thesis statement that clearly indicates what you will discuss in body paragraphs.

Body Paragraphs (3 paragraphs):

In body paragraphs, you should describe three subjects at XX.

Each body paragraph must contain a topic sentence, background information, and a supporting idea with details.

\section{Concluding Paragraph:}

At the beginning, you will restate the thesis statement and then briefly summarize the main ideas you discussed in the body paragraphs. At the end, express your thoughts about the main point you made.

\section{Appendix D}

Students' Questionnaire After the Lessons

\author{
Essay Writing振り返りシート \\ Essay Writing: Questionnaire \\ (Sachi Oshima)
}

このシートは、皆さんにEssay Writingに取り組んだ内容をふり返っていただくためのものです。 記載内容は、成績には一切影響せず、記名の必要もありません。

遠慮なく、自由にコメントを記入してください。

This questionnaire is conducted for you to review your essay writing.

Your answer will not affect the course grade. You do not have to write your name.

1. 自分自身のWriting力を振り返って、どのような点が伸びたと思いますか。 What aspects of writing skills do you think were developed?

2.Writingの向上に、何が役立った(助けになった)と思いますか。 What do you think was beneficial for improving your writing?

3. 教師からのフィードバックの方法について、どんな点が最も助けになりましたか。 Regarding the teacher's feedback, what was the most beneficial for improving your writing?

4. その他、Writingの授業について、自由にコメントしてください。

Do you have any other comments about this course? 